\title{
PRAKTIK MARTUPPAK MARTAHI DI DESA SIBARGOT KABUPATEN LABUHANBATU SUMATERA UTARA DITINJAU DARI PERSPEKTIF UTANG PIUTANG
}

\author{
Laila Afni Rambe \\ Universitas Islam Negeri Imam Bonjol Padang, email: lailaafnirambe20@gmail.com \\ (C)2020 by the authors. Submitted for possible open access publication under the terms and conditions \\ of the Creative Commons Attribution (CC-BY-SA) license (https://creativecommons.org/licenses/by-sa/4.0/) \\ do) DOI : $\underline{10.30983 / \text { alhurrivah.v5i2.2939 }}$
}

\begin{tabular}{l|l|l} 
Diterima: 26 Januari 2020 & Direvisi: 20 September 2020 & Diterbitkan: 31 Desember 2020
\end{tabular}

\begin{abstract}
The factors underlying the writer in discussing this title see the Sibargot Village community doing Martuppak. Martabi practices in the Walimah program. Then there is a repayment of money that has been given in Walimah, furthermore it is not known included in the payment of accounts payable or only limited to giving. Whereas in Islam, the loan receivables contract must be clear, both in terms of payment time and in terms of the amount of money that must be paid. The purpose of this research is to find out the practice of Martuppak. Martabi in the W alimah event in Sibargot Village in terms of Debt Debt Perspectives. The method used is field research using interview techniques. Then the data is analyzed using qualitative descriptive analysis methods. From the results of the analysis conducted by the author on these data it can be concluded that according to the perspective of accounts receivable debt, Martuppak. Martabi practices are not accounts receivable debt, but are included in the giving off and this is permissible.
\end{abstract}

Keywords: Accounts Payable, Martuppak Martahi, Walimah.

\begin{abstract}
Abstrak
Faktor yang melatarbelakangi penulis dalam membahas judul ini melibat masyarakat Desa Sibargot melakukan praktik. Martuppak. Martahi dalam acara walimah. Kemudian adanya pembayaran kembali uang yang telab diberikan di walimah, selanjutnya bal itu tidak diketabui termasuk dalam pembayaran utang piutang atau hanya sebatas pemberian semata. Sedangkan dalam Islam, akad utang piutang yang dilakukan harus jelas, baik dari segi waktu pembayaran maupun dari segi jumlah uang yang harus dibayarakan. Adapun tujuan dalam penelitian untuke mengetahui praktik. Martuppak. Martahi dalam acara walimah di Desa Sibargot ditinjau dari perspektif utang piutang. Metode yang digunakan yaitu penelitian lapangan dengan menggunakan teknik wawancara. Kemudian data tersebut dianalisis dengan menggunakan metode analisis deskriptif kualitatif. Dari hasil analisis yang penulis lakukan terhadap data tersebut dapat disimpulkan bahwa menurut perspektif utang piutang praktik Martuppak Martabi bukanlah merupakan utang piutang tapi termasuk kepada pemberian lepas dan praktik tersebut boleh dilakukan.
\end{abstract}

Kata Kunci: Utang Piutang, Martuppak Martahi, Walimah.

\section{PENDAHULUAN}

\section{Latar Belakang}

Kekayaan suku bangsa dan budaya menjadi ciri unik tersendiri yang dimiliki
Indonesia. Mulai dari suku Jawa, Minang, Melayu, Batak dan lain sebagainya. Keberagaman adat juga dimiliki oleh desa 
Sibargot yang terletak di provinsi Sumatera Utara.

Desa Sibargot Kabupaten Labuhanbatu Kecamatan Bilah Barat merupakan daerah yang terletak di dataran tinggi. Desa Sibargot Kabupaten Labuhanbatu Kecamatan Bilah Barat tergolong daerah yang berkembang. Pembangunan sarana dan prasarana dapat dikatakan sudah memiliki kemajuan baik dibidang pendidikan maupun teknologi. Daerah Sibargot terdiri dari delapan Dusun yaitu Dusun Padang Rapuan, Padang Haloban, Lokasi I, Lokasi II, Barussalam, Sipirok Indah, Kampung Baru dan Aek Gambir. Dengan begitu banyaknya Dusun di Desa Sibargot sama halnya pula dengan banyaknya kuantitas jumlah penduduknya yang mana mata pencaharian masyarakat pada umumnya adalah bertani.

Sebagai masyarakat adat tentunya masyarakat Desa Sibargot juga memiliki banyak aneka ragam adat istiadat yang telah menjadi kebiasaan dan telah menjadi rutinitas, baik dalam bidang keagamaan, kesenian, maupun perkawinan. Salah satunya dalam prosesi perkawinan ada acara walimab ${ }^{1}$ perkawinan yaitu Martuppak Martabi. Adat ini sudah menjadi hal yang lumrah dilakukan oleh masyarakat setempat dan sudah berlangsung sejak dahulu hingga saat ini tradisi ini masih tetap dilakukan, hal ini dapat dilihat dari setiap walimah perkawinan yang diadakan tidak terlepas dari praktik Martuppak Martahi².

Martuppak Martabi adalah sebuah tradisi dalam sebuah walimah, baik itu walimah karena perkawinan ataupun walimah karena kbitan dan bahkan ada pula yang mengadakan walimah karena syukuran yang dalam acara tersebut

${ }^{1}$ Walimah adalah sebuah pesta yang bertujuan untuk menyebarluaskan berita bahagia. Walimah juga merupakan sebuah kebiasaan penyajian makanan untuk acara pesta dalam rangka ungkapan rasa syukur. Lihat Syaikh Kamil Muhammad Uwaidah, Fiqh Wanita (Jakarta Timur: Pustaka Al-Kautsar, 2006).

2 Mula Tua (Pemuka Agama), Wawancara, 15 Maret 2018. adanya sebuah praktik yaitu memberikan sejumlah uang kepada abli bait yang mana jenis akadnya yaitu dengan akad tulisan.

Akad tulisan yang dimaksud disini yaitu pemberian uang dapat dilakukan dengan memberikan kepada panitia walimah perkawinan dengan syarat panitia walimah menghitung jumlah uang kemudian dicatat dalam buku partabian ${ }^{3}$. Masyarakat setempat hanya akan membayar uang tersebut pada saat walimah perkawinan yang diadakan pihak pemberi uang.

Masyarakat menganggap bahwa praktik Martuppak Martabi ini merupakan salah satu bentuk dari utang piutang yang dilakukan pada saat walimah sebab adanya suatu pemberian uang. Kemudian dalam praktik Martuppak Martahi terdapat suatu kewajiban seseorang untuk membayar kembali uang yang telah diberikan. Hal itu menjadi sebab akibat dari sistem praktik Martuppak Martabi. Adanya hubungan timbal balik antara pemberi uang (tamu undangan walimah perkawinan) dengan penerima uang atau pelaksana walimah perkawinan. $^{4}$

Dengan besarnya modal yang harus dipersiapkan oleh penyelenggara walimah maka utang piutang pun tidak dapat dihindarkan lagi sehingga tradisi Martuppak Martabi menjadi salah satu solusi yang dijalankan masyarakat. Meskipun saat ini banyak bermunculan rasa ketidakpercayaan diantara sesama masyarakat. ${ }^{5}$

Pada praktiknya sebagian masyarakat (penerima uang) sudah mengadakan walimah perkawinan dua sampai tiga kali, yang

${ }^{3}$ Partabian adalah istilah yang digunakan untuk menyebut uang yang akan diberikan atau dibayarkan. Contoh: uang pertahian atau buku partahian (buku yang berisi tentang catatan uang yang diberikan). Lihat Kholillah Lubis (Masyarakat), Wawancara, 18 Oktober 2019.

4 Nurhidayah (Pelaksana Walimah), Wawancara, 10 September 2018.

${ }^{5}$ Hafsah M kamil Srg, Nawir Yuslem, "Tradisi Akad Mandondon Di Masyarakat Tapanuli Selatan Ditinjau Dari Hukum Islam," At-Tafahum: Journal of Islamic Law 2, no. 1 (2018): 101. 
didalamnya terdapat praktik Martuppak Martabi. Namun pihak pemberi uang baru sekali mengadakan walimah sehingga penerima uang akan membayar satu kali saja dikarenakan pihak pemberi uang baru sekali mengadakan walimah perkawinan (Martuppak Martahi). Jadi hitungan pembayaran tersebut dilihat dari berapa banyak jumlah uang yang diberikan pada saat walimah terakhir. Sedangkan uang yang diberikan pada walimah pertama tidak dihitung ${ }^{6}$. Misalnya: Si A mengadakan walimah perkawinan anak pertamanya kemudian mengundang si B untuk datang ke acara tersebut kemudian si B datang dengan membawa uang sebanyak Rp.200.000,- yaitu untuk diberikan kepada si A, kemudian 3 bulan kemudian si A kembali mengadakan walimah perkawinan anak keduanya dan kembali mengundang si $\mathrm{B}$, setelah itu si $\mathrm{B}$ datang ke acara tersebut dengan membawa uang sebanyak Rp.300.000,-. Jadi selama walimah yang diadakan si $\mathrm{A}$, ia telah menerima uang dari si B sebanyak Rp.500.000,- yaitu walimah pertama Rp.200.000,- dan walimah kedua Rp.300.000,-. Berdasarkan hal ini timbullah hubungan timbal balik yaitu si $\mathrm{B}$ mengadakan walimah perkawinan anak pertamanya kemudian mengundang si A, kemudian si A datang dengan membawa uang Rp.300.000,- padahal uang yang diberikan si A kepada si B adalah Rp.500.000,- yaitu hasil kalkulasi dari seluruh uang yang diberikan si B pada saat walimab yang pertama dan terakhir. Jadi dalam Martuppak Martabi ini uang yang harus dibayarkan adalah sesuai dengan uang yang diberikan pada saat walimah terakhir, sehingga uang yang diberikan pada saat walimah perkawinan pertama tidak dihitung.

Sebagai masyarakat muslim tentunya seluruh adat istiadat yang berkembang ditengah-tengah masyarakat haruslah sesuai dengan syariat Islam. Tetapi yang menjadi

6 Samsuddin Hasibuan (Tamu Undangan), Wawancara, 23 September 2017. permasalahan, di dalam Islam istilah dan praktik Martuppak Martabi ini tidak dikenal. Praktik Martuppak Martabi ini yang merupakan praktik kebudayaan dalam perkawinan, apakah termasuk kepada utang pitang atau tidak yang kemudian boleh atau tidak untuk dilakukan sehinga perlu ditinjau lebih lanjut.

Suatu kegiatan muamalah dapat dikatakan utang piutang apabila terpenuhinyaa rukun dan syarat utang piutang. Kemudian utang piutang haruslah dilakukan terhadap barang-barang yang diperbolehkan dalam Islam.

Berangkat dari masalah di atas maka penulis termotivasi untuk mengkaji dan menelitinya secara mendalam dalam bentuk karya ilmiah dengan judul "Praktik Martuppak Martahi di desa Sibargot kecamatan Bilah Barat kabupaten Labuhanbatu Sumatera Utara ditinjau dari perspektif utang piutang".

Studi tentang akad utang piutang ini juga dilakukan oleh penulis lain diantaranya Gemma Sari Harahap dengan judul penelitian praktik pembayaran utang piutang di Desa Pasar Sipiongot Kec. Dolok Kab. Padang Lawas Utara. Permasalahan yang diangkat adalah pihak yang berutang tidak senang dengan transaksi utang piutang yang dilakukan oleh pemberi utang di daerah tersebut, transaksi tersebut terdapat ketidakjelasan pembayaran utang.

Selain itu ada penelitian yang dilakukan oleh Nurdah Yati dengan judul penelitian pelaksanaan utang piutang di Kenagarian Situjuah Gadang Kecamatan Limo Nagari Kabupaten Lima Puluh Kota ditinjau dari hukum Islam. Analisis yang dilakukan fokus pada permasalahan orang-orang yang berutang kepada si pemberi utang memberikan nilai tambahan atas pengembalian uang yang dipinjamkan dan tambahan tersebut berupa bunga. Sedangkan dalam Islam hal tersebut pengenaan bunga terhadap utang adalah haram hukumnya. 
Adapula penelitian yang dilakukan oleh Noor Fanika dan Ashif Az Zafi dengan judul penelitian pandangan Islam terhadap adat kebiasaan hutang piutang masyarakat desa Daren kecamatan Nalumsari kabupaten Jepara. Penelitian ini membahas adanya penambahan yang menjadi syarat pengembalian hutang. ${ }^{7}$

Penelitian selanjutnya dari Dandkf Syari dengan judul perjanjian utang piutang dalam tradisi sumbangan pernikahan. Fokus kajian dalam penelitian ini berada pada kajian antropologi dengan melihat anggapan hukum adat terdahap praktik sumbangan dalam perkawinan.

Berdasarkan kajian review di atas maka dapat dilihat adanya perbedaan fokus penelitian dengan yang akan penulis teliti. Penulis menganalisis dari perspektif utang piutang yang kemudian melahirkan kajian hukum Islam (istimbat hukum). Dengan tetap melihat relasi antara adat dan hukum Islam. Kajian ini perlu dilakukan dengan pertimbangan praktik adat yang terus menerus dilakukan bahkan tidak hanya dilokasi penelitian. Sehingga perlu dianalisis apakah adat tersebut bertentangan dengan syariah atau tidak.

Adapun yang menjadi pertanyaan penelitian yakni bagaimana praktik Martuppak Martahi ditinjau dari perspektif utang piutang dalam acara walimah di Desa Sibargot Kecamatan Bilah Barat Kabupaten Labuhanbatu Sumatera Utara. Sehingga dengan terjawabnya pertanyaan penelitian maka dapat diketahui seperti apa praktik Martuppak Martabi dalam perspektif utang piutang.

Dengan adanya hasil penelitian ini maka terlihat adanya relasi antara adat/tradisi dengan hukum Islam. Di samping itu penulis berharap

7 Noor Fanika dan Ashif Az Zafi, "Pandangan Islam Terhadap Adat Kebiasaan Hutang Piutang Masyarakat Desa Daren Kecamatan Nalumsari Kabupaten Jepara," Tafqquh: Jurnal Hukum Ekonomi Syariah Dan Akhwal Syakhsiyah 5, no. 1 (2020): 1. bagi seluruh pembaca sekaligus sebagai masyarakat yang beradat bahwa dalam melaksanakan sebuah praktik muamalah yang telah menjadi adat dapat dilihat lebih jauh terlebih dahulu kemudian diadakan pengkajian lebih mendalam, apakah adat yang telah berkembang di masyarakat tersebut sesuai dengan anjaran Islam atau sebaliknya. Sehingga dapat diketahui adat yang dijalankan itu merupakan adat yang shahih atau tidak.

Adapun kegunaan dari penelitian ini yaitu:

1. Sebagai bahan untuk menambah wawasan dan pengetahuan bagi masyarakat yang melakukan praktik utang piutang Martuppak Martabi dalam acara walimah.

2. Sebagai bahan untuk menambah ilmu pengetahuan di bidang hukum ekonomi syariah/muamalah.

3. Sebagai wacana bagi seluruh masyarakat khususnya masyarakat yang melakukan praktik Martuppak Martabi dalam acara walimah di Desa Sibargot Kecamatan Bilah Barat Kabupaten Labuhanbatu Sumatera Utara. Agar tercapainya tujuan penelitian pada poin ke tiga, penulis akan memberikan hasil penelitian kepada pihak pemerintah desa, pemangku adat atau cerdik pandai serta membanyak bard copy artikel untuk diberikan kepada lembaga perpustakaan desa dan lembaga pendidikan di sekitar lokasi penelitian.

\section{Metode Penelitian}

Jenis penelitian yang penulis lakukan dalam pembahasan permasalahan ini ialah penelitian hukum sosial (social legal research) yang mana data tersebut diperoleh melalui:Penelitian lapangan (field reseach). Selain itu penulis juga memperoleh data melalui penelitian pustaka (library research. Teknik pengumpulan data penulis lakukan dengan wawancara. Selain itu juga dengan observasi, yaitu mengamati gejala yang diteliti, dalam hal ini panca indera manusia diperlukan untuk 
menangkap gejala yang diamati yang kemudian apa yang ditangkap tersebut dicatat dan selanjutnya dianalisis. Sumber data penulis adalah sumber data primer, yaitu data yang diperoleh dari lapangan berupa hasil wawancara maupun hasil observasi dari objek penelitian. Orang yang diwawancarai adalah pelaksana walimah sebanyak 9 (sembilan) orang, tamu undangan sebanyak 7 (orang) yang menghadiri walimah, pemuka adat 3 (tiga) orang, pemuka agama serta perangkat Desa di daerah penelitian. Pada observasi, penulis juga mengamati dengan cara ikut berpartisipasi langsung $^{8}$ yaitu partisipan sempurna ${ }^{9}$ sebagai tamu undangan dengan melakukan transaksi kepada pihak pelaksana walimah maupun kepada panitia walimah. Selain sumber data primer ada juga sumber data sekunder, yaitu sumber data yang diperoleh dari buku-buku yang berkaitan dengan penelitian ini. Dalam teknis analisis data penulis mengunakan analisis deskriptif kualitatif, yaitu menggambarkan permasalahan yang terjadi di lapangan sesuai apa adanya. Analisis data ini dilakukan dengan mengklasifikasikan data dan menggambarkannya. Setelah data itu terkumpul baik data melalui observasi, wawancara yang berkaitan dengan data yang dibutuhkan dalam penelitian ini maka teknik pengolahan datanya dilakukan dalam beberapa tahapan. Tahap pertama pengelolaan data dimulai dari penelitian pendahuluan hingga tersusunnya usulan penelitian. Tahap kedua, pengelolaan data yang lebih mendalam dilakukan dengan cara mengolah hasil kegiatan wawancara dan pengumpulan berbagai informasi lapangan. Tahap ketiga, setelah itu dilakukan pemeriksaan keabsahan data hasil wawancara dengan sejumlah narasumber yang dijadikan informan penelitian serta

${ }^{8}$ Partisipan sempurna yaitu pengamatan secara langsung dengan cara, peneliti terlibat langsung dengan masyarakat yang sedang diamatinya.

${ }^{9}$ John W Creswell, Penelitian Kualitatif Dan Desain Riset (Yogyakarta: Pustaka Pelajar, 2014). 232. membandingkan data tersebut dengan berbagai informasi terkait. Pada tahap ini, pengolahan data dianggap optimal apabila data yang diperoleh sudah layak dianggap lengkap dan dapat merepresentasikan masalah yang dijadikan objek penelitian. Tahap akhir adalah analisis data dalam rangka menjawab pertanyaan-pertanyaan penelitian yang dilakukan dengan pendekatan analisis deskriptif.

\section{Praktik Martuppak Martahi didesa Sibargot Kecamatan Bilah Barat Kabupaten Labuhanbatu Sumatera Utara}

Praktik-praktik kebiasaan masyarakat yang tumbuh menjadi adat istiadat hingga saat ini terus dipertahankan oleh masyarakat dalam bentuk kearifan lokal (indiginius local). Adat inilah yang kemudian hadir dan berkembang dalam suatu kesatuan komunitas sebagai campuran dari sebuah tatanan geneologis dan teritorial. Seperti contohnya dalam budaya Batak Mandailing Martuppak Martabi. ${ }^{10}$

Martuppak Martabi adalah sebuah tradisi dalam sebuah walimah yaitu tamu undangan memberikan sejumlah uang kepada abli bait yang mana pemberiannya dapat dilakukan dengan memberikan uang langsung kepada abli bait atau diwakilkan kepada panitia walimah. Masyarakat setempat hanya akan membayar uang yang telah diterima pada saat walimah yang diadakan pihak pemberi uang tersebut.

Uang yang akan diberikan itu diistilahkan dalam masyarakat Batak Mandailing sebagai partabian. Berkenaan dengan pemberian uang dalam walimah, tamu undangan yang hadir akan dijamu dengan aneka macam makanan yang telah disediakan oleh abli bait melalui panitia walimah (prasmanan). Uang partabian dikumpulkan oleh panitia walimah dan di malam puncak walimah tersebut akan dihitung jumlah keseluruhannya kemudian langsung diserahkan kepada pelaksana walimah.

10 Jemmy Sondakh et.al, "Sistem Adat Pada Mapalus Rumah Etnis Tonsawang Di Tombatu Minahasa Tenggara," Lex Et Societatis 4, no. 8 (2020.): 63. 
Waktu pelaksanaan Martuppak Martabi ini tentunya dilakukan pada saat walimah yang biasanya akan menghabiskan waktu 2 hari. Uang partabian mulai dikumpul saat pagi hari setelah prosesi akad nikah selesai dilakukan dan berakhir pada saat walimah selesai dilaksanakan. Praktik martupak martahi ini sudah menjadi kebiasaan ditengah-tengah masyarakat yang pelaksanaannya pada saat walimah. Sedangkan di hari lain praktik ini tidak dilaksanakan karena memang kebiasaannya masyarakat akan melaksanakan Martuppak Martahi pada saat walimah saja.

Ketentuan umum praktik Martuppak Martabi yaitu tamu undangan akan hadir berdasarkan undangan yang disampaikan langsung atau diberikan undangan khusus oleh pelaksana walimah. Proses pemberian uang partabian diawali dengan datangnya para tamu undangan ke acara walimah. Selanjutnya menyerahkan uang partahiannya kepada panitia untuk dicatat. Namun sebahagian masyarakat ada juga yang memberikan uang langsung kepada abli bait, tentunya uang tersebut dimasukkan ke dalam sebuah amplop yang telah diberi keterangan nama serta alamat pemberi.

Pemberian uang dalam sebuah walimah disebut oleh masyarakat dengan praktik utang piutang. Hingga saat ini praktik Martuppak Martahi ini selalu dilakukan oleh masyarakat. Adapun contoh praktiknya yaitu: pak ZamZam Rambe melaksanakan walimah atas perkawinan anak pertamanya yang kemudian mengundang pak Ali Manan Pohan, kemudian selanjutnya pak Ali Manan datang ke walimah tersebut dengan membawa uang Rp. 300.000,dengan penyerahan uang diberikan kepada panitia walimah yang memang sudah ditugaskan untuk mencatat seluruh uang yang diberikan tamu undangan. Lalu beberapa bulan kemudian pak Ali Manan Pohan mengadakan walimah dengan mengundang pak Zam-Zam untuk datang dalam acara walimah tersebut, yang mana pak Zam-Zam juga membawa uang sebanyak Rp. 320.000,- kelebihan Rp. 20.000,dari uang yang diberikan tersebut dikategorikan oleh masyarakat sebagai tanda terima kasih.

Pada praktik Martuppak Martabi masyarakat hanya menggunakan istilah utang piutang saja namun untuk ketentuan utang piutang tersebut berada dalam ketentuan adat. Hal ini bermakna, bahwa utang piutang dalam ketentuan adat itu tidak memiliki kewajiban untuk membayar. Kemudian utang piutang tersebut juga tidak mengakibatkan adanya hak dari tamu undangan untuk menagihnya. Meskipun praktik Martuppak Martabi ini berada dalam ketentuan adat namun tidak ada sanksi adat yang diterapkan apabila uang yang dibayarkan tidak dikembalikan.

Berdasarkan penelitian yang telah dilakukan, praktik Martuppak Martahi ini termasuk kepada utang piutang dalam ketentuan adat. Utang piutang dalam hal ini tidak sama dengan ketentuan utang piutang dalam Islam yang dibawa hingga mati, kemudian adanya kewajiban untuk membayar. Bahkan pemberi uang berhak untuk menagihnya. Hal ini disimpulkan dengan melihat pelaksanaannya di masyarakat yang mengistilahkan praktik Martuppak Martabi dengan utang piutang dengan ketentuan adat. Utang piutang dalam ketentuan adat di desa Sibargot yaitu kesepakatan dalam transaksi utang piutang Martuppak Martabi yang dilakukan secara sederhana tanpa adanya kewajiban untuk membayar utang tersebut. Pelaksanaan utang piutang secara adat ini dilangsungkan hanya berdasarkan pada kebiasaan-kebiasaan yang terjadi dikalangan masyarakat.

Praktik Martuppak Martabi merupakan suatu kebiasaan masyarakat memberikan uang berdasarkan sifat ta'awnn. Pemberian uang tersebut sesuai kesanggupannya saja tidak ditentukan berapa jumlahnya. Kemudian untuk pembayarannya tidak ada diwajibkan, namun masyarakat boleh mengembalikan uang tersebut pada saat walimah yang diadakan oleh orang yang memberikan uang kepada penerima uang di walimah sebelumnya ${ }^{11}$

\section{Penyebab masyarakat melakukan praktik Martuppak Martahi di desa Sibargot Kecamatan Bilah Barat Kabupaten Labuhanbatu Sumatera Utara}

11 Normaiyah Pohan (Tamu Undangan), 10 September 2018. 
Berdasarkan penelitian yang telah dilakukan penulis, penyebab masyarakat melakukan praktik ini disebabkan oleh adanya adat dalam suatu penyelenggaraan perkawinan ini membuktikan bahwa masyarakat masih mempertahankan nilai-nilai yang terkandung dalam praktik Martuppak Martabi. Dengan melakukan praktik Martuppak Martahi, masyarakat adat Mandailing tidak melupakan nenek moyang dan tradisi yang merupakan kewajiban untuk melestarikan dan membudidayakannya, sehingga keturunanketurunan di masa mendatang masih melakukan hal yang sama seperti orang tua mereka.

Selanjutnya, masyarakat setempat menilai bahwa adat merupakan pemersatu bagi para masyarakat. Dalam pelaksanaan perkawinan adat yang umumnya menghabiskan waktu dan persiapan yang panjang dapat mempererat tali persaudaraan di antara masyarakat adat Mandailing tersebut. Hal ini membuktikan bahwa kuatnya rasa kekeluargaan yang terjalin antar sesama masyarakat. Selain itu, sifat gotong royong tanpa pamrih akan tetap terpegang teguh.

Keberlanjutan pelaksanaan praktik Martuppak Martahi ini bertujuan untuk melestarikan peninggalan budaya nenek moyang agar tidak luput dimakan zaman. Sebab seiring perkembangan zaman kebudayaan dapat memudar dan berubah apabila tidak dijaga keasliannya. Melestarikan adat wajib dilakukan masyarakat Mandailing meskipun telah hidup di zaman modern. Perkawinan secara adat menunjukkan kebesaran kedudukan masyarakat adat Mandailing tersebut di lingkungan sekitar. Sesederhana apapun acara adat, kita sebagai masyarakat adat harus tetap dengan sungguhsungguh melaksanakannya agar adat tersebut terjaga dan kita sebagai masyarakat tidak dianggap tidak beradat.

Dengan melakukan praktik Martuppak Martahi dalam walimah semakin meningkat rasa kekeluargaan antar sesama masyarakat karena dalam praktik tersebut adanya sifat ta'awnn. Suatu kegiatan saling tolong menolong tersebut tentunya tanpa mengharapkan pamrih, karena dalam ta'awun tidak dipermasalahkan tentang siapa yang ditolong dan siapa yang menolong serta tidak melihat pangkat, derajat ataupun harta seseorang.

\section{Praktik Utang Piutang Martuppak Martahi di Desa Sibargot Kecamatan Bilah Barat Kabupaten Labuhanbatu Sumatera Utara ditinjau dari Perspektif Utang Piutang}

Secara etimologi utang piutang disebut dengan القرضy yang berasal dari kata qaradha, sinonim dari kata qatha'a yang berarti memotong atau memutuskan. Dinamakan qardh karena ia adalah sebagian dari harta muqridh (qith'atun min mali'l muqridb). ${ }^{12}$ Sedangkan dalam kamus besar bahasa Indonesia kata utang berarti uang yang dipinjam dari orang lain, kewajiban membayar kembali apa yang sudah diterima dan kata piutang bermakna uang yang dipinjamkan kepada orang lain dan dapat ditagih.

Utang piutang dalam arti terminologi digunakan dua istilah al-qardhu (القرض) dan dayn kedua lafaz ini terdapat didalam Al-Qur'an dan hadis Nabi dengan maksud yang sama yaitu utang piutang. ${ }^{13}$ Defenisi utang piutang tersebut yang lebih mendekat kepada pengertian yang mudah dipahami adalah penyerahan harta berbentuk uang untuk dikembalikan pada waktunya dengan nilai yang sama. Kata "penyerahan harta" disini mengandung arti pelepasan kepemilikan dari yang punya. Kata "untuk dikembalikan pada waktunya" mengandung arti bahwa pelepasan pemilikan hanya berlaku untuk sementara,

${ }^{12}$ Muhammad Rifqi Arriza, "Teori Dan Praktek Akad Qardh (Hutang-Piutang) Dalam Syariat Islam," Ijtihad 9, no. 2 (2015): 245.

13 Tri Almunawawarah dan Muhammad Ngasifuddin, "Praktik Utang Piutang Dalam Membangun Rumah Dengan Sistem 'Titip' Dilihat Dari Perspektif Ekonomi Syariah,” Al-Intaj: Fakultas Ekonomi Dan Bisnis Islam IAIN Bengkulu 5, no. 1 (2019): 121. 
dalam arti yang diserahkan itu hanyalah manfaatnya ${ }^{14}$.

\section{Rukun dan Syarat Utang Piutang}

1. 'Aqid, yaitu muqridh dan muqtaridh. Untuk aqid disyaratkan harus orang yang disyaratkan harus orang yang dibolehkan melakukan tasaruff atau memiliki abliyatul ada'.

a. Berakal. Tidak sah akad (dalam hal ini utang piutang) yang dilakukan oleh orang yang tidak waras (gila).

b. Atas Kehendak sendiri. Maksudnya akad yang dilakukan oleh para pihak dalam utang piutang itu harus atas kehendak sendiri tanpa ada paksaan atau tekanan dari pihak manapun. Kehendak sendiri atas persetujuan kedua belah pihak yang merupakan unsur penting dalam akad utang piutang.

c. Baligh. Tidak sah akad utang piutang yang dilakukan oleh orang yang belum baligh (anak-anak) karena seorang anak belum cakap melakukan tindakan hukum.

d. Tidak di bawah perwalian. Dalam setiap hukum Islam tidak semua orang dipandang cakap melakukan tindakan hukum walaupun dari segi umur telah dewasa, seperti yang dikemukakan oleh Ahmad Azhar Basjir menyatakan bahwa dalam melakukan akad orang yang dipandang tidak cakap melakukan akad maka akad tersebut tidak ada nilainya ${ }^{15}$.

\section{Ma'qud 'alaih, yaitu uang atau barang}

Menurut jumhur ulama yang menjadi objek akad dalam qardh sama degan objek akad salam. Baik berupa barang-barang yang ditakar dan ditimbang maupun qimiyat

14 Amir Syarifuddin, Garis-Garis Besar Fiqh (Jakarta: Kencana, 2010). 222.

15 Ahmad Azhar Basjar, Asas-Asas Hukum Muamalah (Jakarta, n.d.) 53. (barang-barang yang tidak ada persamaannya di pasaran, seperti hewan, barang-barang dagangan, dan barang yang dihitung. Dengan perkataan lain, setiap barang yang boleh dijadikan objek jual beli boleh juga dijadikan objek akad qardh.

\section{Shigat}

Shigat akad terdiri dari ijab dan qabul. Ijab dan qabul merupakan sebuah ungkapan dari kedua belah pihak berakad yang menunjukkan kerelaan keduanya untuk melakukan transaksi utang piutang. ${ }^{16}$

Hukum transaksi utang piutang dapat menjadi wajib atas seseorang yang memiliki kelebihan harta. Artinya ia mampu menolong orang yang sangat membutuhkan dengan hartanya. Maksud dari "membutuhkan" disini yakni apabila seseorang tersebut tidak diberikan pinjaman uang maka ia akan teraniya atau berpotensi melakukan perbuatan yang dilarang oleh agama. Seperti mencuri karena tidak mempunyai biaya untuk memenuhi kebutuhan pokoknya. ${ }^{17}$ Hukum utang piutang juga dapat berubah menjadi haram apabila utang piutang tersebut berorientasi pada perbuatan tolong menolong dalam kemaksiatan.

\section{Hikmah dan Tujuan Utang Piutang}

\section{Hikmah Utang Piutang}

a. Menumbuhkan atau mempererat ukhuwah Islamiyah

Menurut ajaran Islam semua manusia adalah bersaudara, seperti yang dijelaskan dalam firman Allah SWT dalam Surat alHujurat ayat 10 yang berbunyi:

16 Abdul Aziz dan Ramdansyah, "Esensi Utang Dalam Konsep Ekonomi Islam,” Bisnis 4, no. 1 (2016): 128.

17 Adi Cahyadi, "Mengelola Hutang Dalam Perspektif Islam," Esensi: Jurnal Bisnis Dan Manajemen 4, no. 1 (2014): 2. 


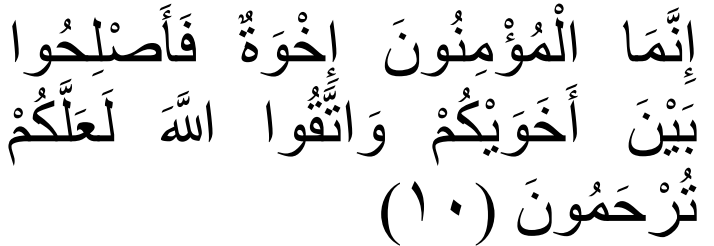

Artinya: Orang-orang beriman itu sesunggubnya bersaudara. Sebab itu damaikanlah (perbaikilah hubungan) antara kedua saudaramu itu dan takutlab terbadap Allah, supaya kamu mendapat rahmat.

Surah al-Hujurat ayat 10 sebagaimana tersebut di atas menjelaskan bahwa orangorang muslim di atas dunia adalah bersaudara dimana ada ikatan sosial diantara sesamanya. Menurut Quraish Shihab semua manusia adalah bersaudara, persaudaraan itu dapat ditemukan dalam empat hal, diantaranya Ukhuwah FiddinalInsaniyab dalam arti umat manusia keseluruhan adalah bersaudara karena mereka itu berasal dari ayah dan ibu yang sama (Adam dan Hawa). Persaudaraan itu harus dijalin karena adanya ikatan agama ${ }^{18}$.

Salah satu cara menumbuhkan tali persaudaraan adalah dengan membantu meringankan beban penderitaan orang lain, dengan sendirinya tali persaudaraan itu akan tercipta, selain itu persaudaraan bukan hanya sekedar memberi dan menerima, melainkan juga memberi pertolongan tanpa mengharapkan imbalan apapun dari pihak yang berutang tapi semata-mata hanya mengharapkan pahala ridha Allah SWT. Sedangkan bagi pemilik harta, dengan adanya kegiatan hutang piutang ini dapat menghindarkan diri dari sifat egois dan tamak dengan cara merelakan sebagian hartanya yang dimiliki untuk dapat dinikmati oleh orang yang menerimanya.

b. Sarana untuk mendekatkan diri pada Allah SWT
Segala yang ada di langit dan di bumi adalah milik Allah SWT yang dititipkan kepada makhluknya untuk melangsungkan kehidupan. Dapat kita sadari bahwa semua yang dimiliki bukan milik sendiri tapi hanya sebagai hak pakai untuk sementara dan hendaklah manusia melepaskannya dengan penuh kerelaan terhadap harta yang diperoleh dengan susah payah untuk dipergunakan oleh saudaranya yang membutuhkan baik melalui infak, sadaqah, maupun pinjam meminjam (qardh).

Pada hakekatnya semua rezeki yang diberikan Allah SWT kepada siapa saja adalah untuk memenuhi kebutuhan hamba-Nya sebagaimana yang dikemukakan oleh Sayyid Sabiq dalam kitab fiqh Sunnah bahwa pinjam meminjam (qardh) merupakan salah satu jenis pendekatan untuk ber-taqarrub kepada Allah SWT. Karena pinjam meminjam (qardb) mempunyai arti lemah lembut kepada manusia, mengasihi mereka, memberikan kemudahan dalam urusan mereka, dan memberikan jalan keluar dari duka dan kabut yang menyelimuti kehidupan mereka ${ }^{19}$.

c. Menguatkan iman dan menambah rasa syukur

Kehidupan di dunia hanyalah sementara sedangkan kehidupan di akhirat adalah kehidupan yang kekal dan abadi, setiap manusia dapat memetik amal yang diperbuat selama hidup di dunia, mematuhi segala aturan Allah SWT dengan segala yang diperintahkan dan menjauhi segala larangan-Nya itulah yang akan memberikan kebahagiaan di dunia maka manusia akan semakin yakin untuk menjalankan perintah Allah SW'T,
${ }^{18} \mathrm{M}$ Quraish Shihab, Tafsir Al-Misbah (Jakarta: Lentera Hati, 2002).
${ }^{19}$ Sabiq Sayyid, Figh Al-Sunnah (Beirut: Dar AlFikr, n.d.) 129. 
dengan demikian manusia akan mensyukuri nikmat yang telah diberikan Allah SWT kepadanya.

Semakin tinggi rasa syukur seorang hamba maka ia semakin dapat merasakan dan menikmati hidup ini yang merupakan buah dari iman yang didambakan oleh setiap muslim. Salah satu indikasi iman dan rasa syukur atas karunia Allah SWT adalah kerelaan dalam membantu saudaranya yang membutuhkan dengan memberikan piutang.

d. Meningkatkan taraf ekonomi masyarakat Firman Allah SWT dalam surah alBaqarah ayat 245 yang berbunyi.

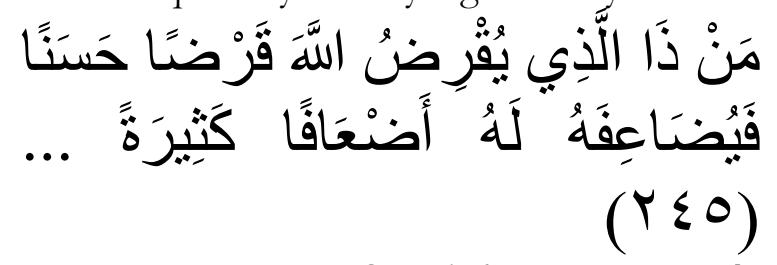

Artinya: Siapakah yang mau memberi pinjaman kepada Allah, pinjaman yang baik. (menafkabkan bartanya di jalan Allab), maka Allah akan meperlipat gandakan pembayaran kepadanya dengan lipat ganda yang banyak ${ }^{20}$.

Ayat di atas menerangkan bahwa apabila seseorang mau memberikan piutang kepada saudaranya yang kurang mampu maka sama maknanya dengan mempiutangi kepada Allah SWT, artinya harta yang direlakan sebagian untuk dinafkahkan di jalan Allah SWT, akan dibalas oleh Allah SWT dengan berlipat ganda melalui rezeki yang lain.

Dibolehkannya pinjam meminjam (qardh) dalam Islam menyebabkan ekonomi masyarakat dapat ditingkatkan, karena kekurangan harta ataupun kebutuhan hidup lainnya dapat dipenuhi dengan cara mengutang terlebih dahulu, sampai ada kelapangan dan kelonggaran

20 Departemen Agama, Al-Qur'an Dan Terjemahannya (Bandung: CV Penerbit J-ART, 2004). 60. dari suatu kesulitan. Memberi piutang, zakat, infak dan sadaqah tidak akan merugikan seseorang bahkan itu dapat membantu pemerintah dalam menuntaskan kemiskinan.

Kemudian bagi penerima hutang hendaknya bahwa perkara hutang merupakan hal yang wajib yang harus diselesaikan oleh orang yang bersangkutan karena akan menjadi beban di akhirat kelak. Apabila mengalami kesulitan dalam membayarnya dianjurkan kepada yang memberi hutang untuk menyedeqahkan dan tidak menuntut pembayaran.

e. Sarana melatih kesabaran diri

Kehidupan manusia mengalami pasang surut ada masa-masa percobaan yang telah diberikan Allah SWT, seperti kelaparan, ketakutan dan kekurangan harta atau jiwa karena itu menuntut manusia untuk sabar, dan bertawakal kepada Allah SWT dalam menghadapi cobaan $^{21}$.

Cobaan itu mungkin dapat dikurangi dengan minta pertolongan atau minta bantuan berupa piutang, dari orang lain dan bagi pemberi piutang diharapkan sabar, jika penerima hutang belum mampu untuk mengembalikan hutangnya maka hendaklah menambah waktu jatuh tempo pembayarannya.

e. Salah satu sarana beribadah kepada Allah SWT

Memberikan piutang berarti seseorang telah memberikan kelapangan bagi saudaranya yang dalam kesusahan dan kelak di akhirat Allah SWT akan memberikan kelapangan atas amal yang diperbuatnya di dunia. Bagi orang yang

${ }^{21}$ A. Rahman Doi, Muamalah Syariah III (Jakarta: Raja Grafindo, 1996). 79. 
memberi piutang sebanyak dua kali maka yang satu kalinya bernilai sadaqah di sisi Allah SWT.

f. Menjauhkan diri dari perbuatan dosa Apabila seseorang dalam kesulitan dan tidak menemukan orang yang mau memberikan pinjaman, apabila masalah perut maka tidak heran jika terjadi halhal yang merugikan seperti mencuri, merampok, menodong bahkan membunuh jika itu salah satu cara untuk mengganjal perut. Hal itu tidak perlu terjadi apabila ada sebagian dari mereka yang mau memberikan pinjaman untuk memenuhi kebutuhan hidupnya mereka bisa berfikir kalau ada jalan baik mengapa harus menempuh jalan yang buruk dan beresiko tinggi.

g. Sarana meningkatkan taraf pendidikan

Bolehnya hukum hutang piutang secara tidak langsung seseorang telah membantu meningkatkan taraf pendidikan, dimana uang yang dipinjamkan tersebut sering digunakan untuk biaya pendidikan anak-anaknya. Jadi seseorang yang hidup dengan ekonomi yang lemah juga bisa melanjutkan sekolah anak-anaknya keperguruan tinggi melalaui pinjam meminjam (qardh).

\section{Tujuan Utang Piutang}

Qardh atau utang piutang salah satu bentuk ibadah untuk mendekatkan diri kepada Allah SWT. Sebab dengan memberikan uang atau barang yang lain berarti menyayangi manusia, mengasihi mereka, memudahkan urusan mereka dan menghilangkan kesusahan mereka. Islam menganjurkan dan menyarankan bagi orang yang berkecukupan untuk memberi pinjaman. Islam juga membolehkan orang yang berkesusahan untuk menerima hutangan dari orang yang menghutanginya dan tidak termasuk orang yang meminta-minta. Sebab orang yang meminjam atau berutang mengambil harta atau barang dan dimanfaatkan untuk memenuhi kebutuhannya. Setelah itu, dia mengembalikan harta atau barang yang dipinjamnya ${ }^{22}$.

Utang piutang atau yang dikenal juga dengan istilah qardh berasal dari bahasa arab yaitu qaradha yang berarti memotong. Diartikan demikian karena orang yang memberikan utang memotong sebahagian dari hartanya untuk diberikan kepada orang yang menerima utang. Sedangkan menurut istilah, utang piutang adalah suatu akad yang antara dua pihak yang mana pihak pertama memberikan uang kepada pihak kedua untuk dimanfaatkan sesuai dengan ketentuan yang telah disepakati. ${ }^{23}$ Utang piutang menurut KBBI (Kamus Besar Bahasa Indonesia) yaitu yang dipinjamkan dari orang lain. Sedangkan piutang mempunyai arti uang yang dipinjamkan ${ }^{24}$.

Sebagaimana hadis Rasulullah SAW

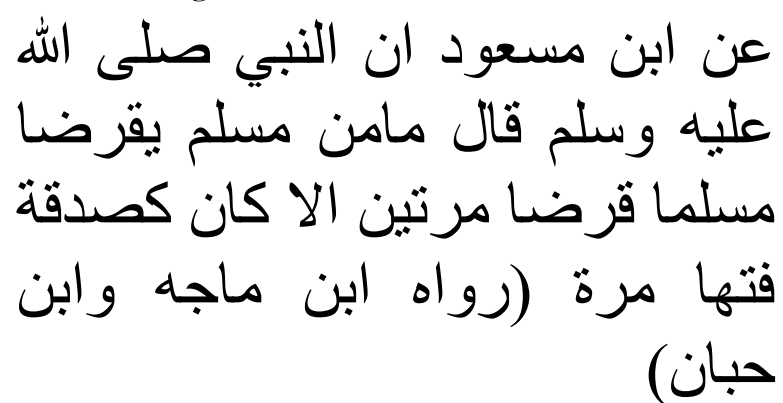

Artinya: 'Dari Ibn Mas'ud babwa Rasulullah $S A W$ bersabda tidak ada seorang muslim mempiutangi orang muslim lain dua kali malahan hal itu adalah seperti mensedekabkan satu kali dari padanya $^{25}$.

Setelah dianalisis, berawal dari pemberian uang yang secara berkelanjutan

${ }^{22}$ Yuswalina, "Hutang Piutang Dalam Perspektif Fiqh Muamalah Di Desa Ujung Tanjung Kecamatan Banyuasin," Intizar 19, no. 2 (2013): 444.

23 Ahmad Wardi Muslich, Figh Muamalah (Jakarta: Amzah, 2013), 444.

24 Poerwadarminto, Kamus Besar Bahasa Indonesia (Jakarta: Balai Pustaka, 2013), 1136.

25 M Asy Syaukan, Alnail Al Autar (Beirut: Thaba' atil As-Sani, 1997), 243. 
kemudian berkembang ditengah-tengah masyarakat, sehingga menjadi kebiasaan kemudian menjadi sebuah adat. Sehingga Martuppake Martabi itu dianggaplah sebagai utang piutang. Bahwa permasalahan utang piutang yang terdapat dalam praktik Martuppak Martahi terjadi di desa Sibargot tidaklah utang piutang dalam ketentuan hukum Islam. Tetapi yang terjadi adalah mengistilahkan Martuppak Martahi dengan utang piutang. Namun pada dasarnya Martuppak Martabi ini adalah pemberian uang dengan seikhlasnya.

Perilaku Martuppak Martabi dalam perkembangannya dianggap wajar oleh masyarakat karena berdampak pada peningkatan keharmonisan sosial masyarakat. Martuppak Martabi menjadi salah satu bagian dari tolong menolong sehingga sudah seyogianya perbuatan tolong menolong dilakukan tanpa pamrih. ${ }^{26}$ Kemudian jika dilihat dari segi hukum adat yang ada di daerah lokasi penelitian, fenomena adat tersebut menunjukkan bahwa masyaraktat setempat masih mempertahankan adat yang ada dan terus melestarikannya melalui tradisi Martuppak Martabi. ${ }^{27}$

Martuppak Martahi dengan istilah utang ini dibolehkan, karena bisa memberikan bantuan kepada orang lain yang membutuhkan dengan cara memberi uang dan pembayarannya tidak diwajibkan. Uang yang telah diberikan tamu undangan boleh dikembalikan dan boleh tidak dikembalikan serta tidak memiliki saksi adat apabila tidak dikembalikan. Berdasarkan hal tersebut, bagi masyarakat yang sudah pindah domisili tidak ada kewajiban untuk membayar uang yang telah diterimanya begitu juga hal nya dengan masyarakat yang tidak pernah melaksanakan walimah tidak ada hak untuk menagih uang yang telah ia berikan. Masyarakat hanya

26 Noor Fanika, "Pandangan Islam Terhadap Adat Kebiasaan Hutang Piutang Masyarakat Desa Daren Kecamatan Nalumsari Kabupaten Jepara," Tafaqqub: Junal Hukum Ekonomi Dan Ahawl as Syahsiyah, n.d., 32 .

27 Giyoto Diantoro, "Perlindungan Hukum Terhadap Pelaku Perjanjian Adat Dalam Transaksi Utang Piutang Dalam Perspektif Hukum (Studi Kasus Pada Unit Simpan Pinjam Masyarakat Di Desa Tenggak Kec. Sodoharjo Kab Sragen," Jurisprudence 4, no. 2 (2014): 115. menganggap kegiatan Martuppak Martabi sebatas investasi akhirat yang diniatkan hanya untuk mengharap ridho Allah swt. ${ }^{28}$

Saling tolong menolong dalam Islam sangatlah dianjurkan, tolong menolong yang dimaksud disini adalah dalam hal kebajikan dan takwa. Bukan dalam perbuatan yang tidak disukai atau yang dilarang Allah SWT. Anjuran saling tolong menolong tersebut berdasarkan ayat firman Afllah SWT Q.S al-Maidah: 2

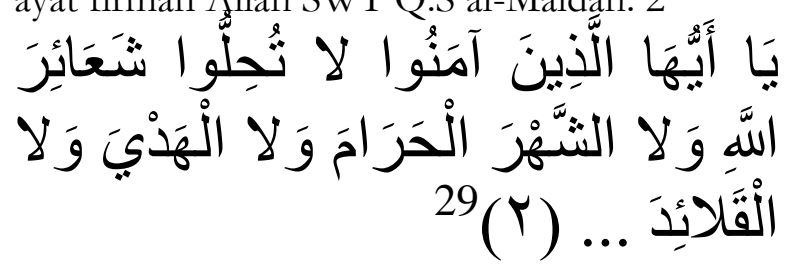

Artinya: Hai orang-orang yang beriman, janganlah kamu melanggar syi'ar-syi'ar Allah dan jangan melanggar kehormatan bulan-bulan haram, jangan (mengganggu) binatang-binatang had-yaad dan binatang-binatang qalaa-id.

Berkaitan dengan praktik utang piutang Martuppak Martabi yang terjadi di desa Sibargot praktik tersebut boleh dilakukan, karena membantu masyarakat dalam melaksanakan walimah. Di dalam praktik Martuppak Martahi masyarakat memiliki rasa saling tolong menolong. Meskipun pembayaran tersebut tidak diwajibkan namun masyarakat yakin bahwasanya Allah SWT-lah yang akan membalas seluruh bantuan tersebut.

Bahwasanya setiap kegiatan muamalah disandarkan kepada sikap saling tolong menolong, saling menghormati, saling mengasihi dalam mencapai tujuan bersama. Hal ini menunjukkan adanya suatu hubungan keperdataan atau hablu minannas antara para pihak yang menganggap diri masing-masing sebagai anggota keluarga, meskipun pada hakikatnya tidak ada hubungan darah. Firman Allah SW'T yaitu Q.S Ali 'Imran : 103

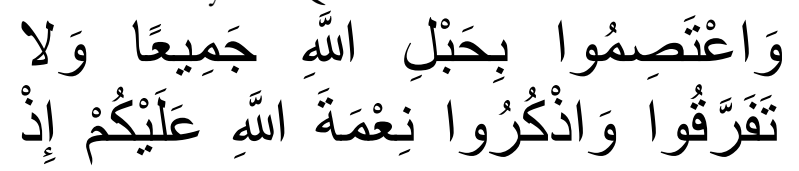

28 Achmad Baihaki dan Evi Malia, "Arisan Dalam Perspektif Akuntansi," Jamal: Jurnal Akuntansi Multiparadigma 9, no. 3 (2019): 122.

29 Departemen Agama, Al-Qur'an Dan Terjemahannya, (Jakarta CV Penerbit J-ART, 2004), 60. 


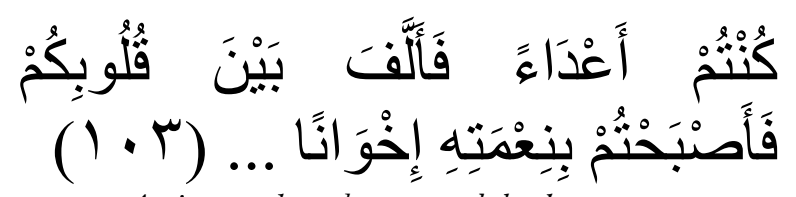

Artinya: dan berpeganglah kamu semuanya kepada tali (agama) Allah, dan janganlah kamu bercerai berai, dan ingatlah akan nikmat Allah kepadamu ketika kamu dabulu (masa Jabiliyab) bermusub-musuban, Maka Allah mempersatukan hatimu, lalu menjadilah kamu karena nikmat Allab, orang-orang yang bersaudara. ${ }^{30}$

Praktik Martuppak Martahi didasarkan juga persetujuan dan kerelaan kedua belah pihak. Persetujuan dan kerelaan kedua belah pihak yang melakukan praktik Martuppak Martahi merupakan sesuatu yang sangat penting $^{31}$. Dilihat dalam praktik Martuppak Martahi terdapat kerelaan kedua belah pihak. Hal tersebut terlihat dari tidak adanya kewajiban untuk mengembalikan uang yang telah diberikan. Sebab praktik ini berdasarkan tolong menolong dengan memberikan bantuan berupa uang atau kain. Pemberian tersebut jatuhnya sebagai bantuan yang mana uang tersebut boleh dikembalikan dan boleh tidak.

Kegiatan adat yang bersifat continue seperti Martuppak Martabi termasuk kedalam bentuk muamalah yang memiliki unsur suka sama suka antara kedua belah pihak yang melakukan transaksi. Sehingga kegiatan tersebut tidak ada paksaan yang dapat menimbulkan kerugian pada salah satu pihak. Sebagaimana disebutkan dalam firman Allah SWT surah an-Nisa' : 29

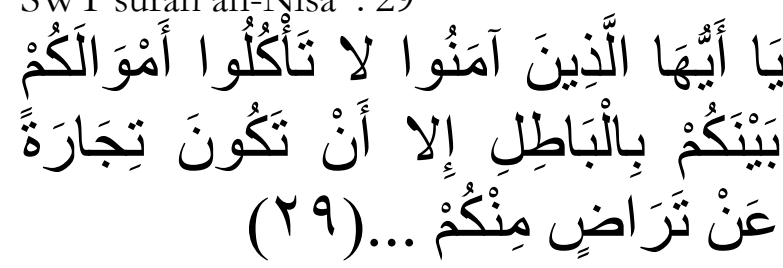

Artinya: Hai orang-orang yang beriman, janganlah kamu saling memakan harta sesamamu dengan jalan yang batil, kecuali dengan jalan perniagaan yang berlaku dengan suka sama-suka di antara kamu. ${ }^{32}$

30 Departemen Agama, Al-Qur'an Dan Terjemahannya, (Bandung: CV Penerbit J-ART, 2004), 63.

31 Ahmad Wardi Muslich, Figh Muamalah, (Jakarta: Amzah, 2013), 3.

32 Departemen Agama, Al-Qur'an Dan Terjemahannya, (Bandung: CV Penerbit J-ART, 2004), 83.
Ayat di atas menjelaskan dasar suka sama suka sebagai syarat bagi syahnya muamalah. Hendaknya muamalah itu dilakukan dengan dasar suka sama suka di antara kedua belah pihak. Kedua, hendaklah keuntungan satu pihak tidak berdiri di atas dasar kerugian pihak lain. Tanpa dilandasi dengan keridhaan, maka seluruh akad dalam muamalah menjadi batal, demikian kedudukan prinsip muamalah menjadi sangat fatal dalam akad-akad yang dibuat dalam muamalah yang dilandasi hukum syariah.

Martuppak Martabi sebagai tradisi atau adat kebiasaan di tengah-tengah masyarakat muslim masih tetap dijalankan hingga saat ini. Hal ini menunjukkan adanya relasi atau hubungan yang memiliki integrasi dan interkoneksi antara adat dan hukum Islam. Hal ini dikuatkan oleh kaidah fikih yang mengatakan bahwa:

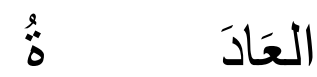

\section{هُهَ}

"Adat dapat dijadikan (pertimbangan dalam menetapkan) bukum"

Kaidah ini menjelaskan bahwa suatu adat yang berada dimasyarakat dapat dijadikan sebuah hukum sehingga dapat dijalankan. Namun perlu dicatat bahwa tidak semua adat dapat dijadikan hukum, indikator yang perlu diperhatikan bahwa adat tersebut tidak bertentangan dengan al-qur'an dan hadis.

Di dalam mazhab Hanafi ditambahkan pula suatu kaidah :
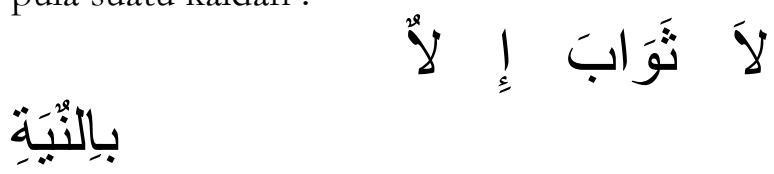

"Tidak ada pabala kecuali dengan niat""33

Merujuk kepada praktik Martuppak Martahi, tidak ditemukan hal-hal menjadikan adat ini bertentangan dengan syariah. Namun sebaliknya dari pelaksanaan serta tujuan yang hendak dicapai melalui praktik ini sungguh sangat mengedepankan syariah dan nilai-nilai keislaman. Sifat gotong-royong dan saling membantu juga mewarni setiap pelaksanaan. Adanya pelaksanaan praktik Martuppak Martahi tentu sangat membantu meringankan beban

33 A. Djazuli, Kaidah-Kaidah Fikih Jakarta: Kencana, 2006), 9. 
dari pihak yang melaksanakan walimah. Disamping itu tidak pula dikesampingkan nilainilai adat yang terus dipertahankan masyarakat yaitu melestarikan budaya, membentuk kepedulian antar sesama masyarakat adat.

Integrasi dan interkoneksi antara nilai adat dan nilai keislaman terlihat dalam praktik Martuppak Martabi. Hal ini tentu menjadi penghubung antara adat dan hukum Islam yang pada dasarnya memiliki relasi sejak dahulu dan berlangsung hingga saat ini.

Relasi ini membuktikan bahwa hukum Islam selalu bergandengan dengan keadaan masyarakat meskipun dengan perubahan sosial yang deras. Itu menandakan bahwa hukum islam selalu merespon permasalahanpermasalahan yang muncul di masa sekarang. Sehingga perlu ditegaskan hukum Islam akan selalu sesuai dengan perkembangan zaman.

Berdasarkan paparan di atas dapat dijelaskan bahwa uang yang diberikan dalam praktik Martuppak Martabi ini merupakan bantuan dalam bentuk materil yaitu pemberian uang dalam rangka tolong menolong sesama masyarakat, mengingat banyaknya modal yang harus dikeluarkan dalam melaksanakan walimah. Kemudian dilihat dari undangan yang disebarkan pelaksana walimab kepada masyarakat, di dalam undangan tersebut tertera undangan Martuppak Martabi kemudian disambung dengan kalimat mohon doa restu dan selamat. Pada undangan tersebut tidak dijelaskan mohon kepada tamu undangan untuk membawa uang. Berdasarkan undangan tersebut berarti tidak ada kewajiban bagi tamu undangan untuk memberikan uang. Namun masyarakat tetap memberikan uang sebagai bentuk rasa kepedulian mengingat bahwasanya manusia sebagai makhluk sosial yang saling membutuhkan.

Dalam hal ini Martuppak Martabi sama halnya dengan pemberian bantuan atau hibah karena kedekatan emosial sesama masyarakat adat. Sehingga ada rasa ikut merasakan momen kebahagiaan, senang dan termasuk didalamnya mendoakan hajat dalam bentuk acara walimah. Sebahagian masyarakat yang menganggap Martuppak Martabi sebagai bentuk utang piutang hanyalah sebuah penyimpangan pemahaman tentang konsep utang piutang dalam Islam. ${ }^{34}$

Praktik Martuppak Martabi yang terjadi di desa Sibargot kecamatan Bilah Barat kabupaten Labuhanbatu yang dilakukan oleh masyarakat bukanlah termasuk utang piutang dalam ketentuan hukum Islam karena tidak terpenuhinya rukun dan syarat dari utang piutang. Selanjutnya dalam praktik Martuppake Martahi tidak terdapat unsur-unsur yang bertentangan dengan ajaran Islam yaitu tidak adanya pihak yang dirugikan, karena pelaksanaan tersebut berdasarkan kerelaan kedua belah pihak. Pemberi uang dalam praktik ini, tamu undangan rela apabila uang yang diberikan tersebut tidak dikembalikan dan ia tidak memiliki hak untuk menagih uang tersebut. Selanjutnya pelaksana walimah tidak memiliki kewajiban untuk mengembalikan uang tersebut.

\section{KESIMPULAN}

Pertama, praktik Martuppak Martahi merupakan kebiasaan masyarakat memberikan uang berdasarkan sifat ta'awun, yang mana pemberian uang tersebut sesuai kesanggupannya saja tidak ditentukan berapa jumlahnya. Kemudian untuk pembayarannya tidak ada diwajibkan, namun masyarakat boleh mengembalikan uang tersebut pada saat walimah yang diadakan oleh orang yang memberikan uang kepada penerima uang di walimah sebelumnya.

Kedua, penyebab praktik Martuppak Martahi adalah karena praktik tersebut merupakan suatu adat istiadat yang secara turun temurun selalu dilakukan oleh masyarakat. Hal ini dilakukan agar adat tersebut terpelihara sehingga tidak sirna ditelan zaman. Penyebab selanjutnya berkaitan tentang kebiasaan masyarakat yang membudayakan sifat saling tolong menolong yang berdasarkan gotong royong tanpa mengharapkan imbalan. Sehingga, dengan sebab itulah sebahagian besar masyarakat melaksanakan praktik Martuppak Martabi.

${ }^{34}$ Eviana Dwi Saputri dan Muhammad Hasyim Ashari, "Tradisi Buwuh Dalam Perspektif Akuntansi Piutang Dan Hibah Di Kecamatan Lowokwaru Kota Malang," Prive: Jurnal Ijtihat, Akuntansi Dan Keuangan 2, no. 1 (2019): 21-22. 
Ketiga, praktik Martuppak Martabi ini termasuk kepada utang piutang dalam ketentuan adat. Utang piutang dalam ketentuan adat di desa Sibargot yaitu kesepakatan dalam transaksi utang piutang Martuppake Martabi yang dilakukan secara sederhana tanpa adanya kewajiban untuk membayar utang tersebut. Utang piutang dalam adat di desa Sibargot itu tidak memiliki kewajiban untuk membayar. Kemudian utang piutang tersebut juga tidak mengakibatkan adanya hak dari tamu undangan untuk menagihnya. Penulis menyimpukan bahwa praktik Martuppak Martahi yang terjadi di desa Sibargot kecamatan Bilah Barat kabupaten
Labuhanbatu adalah bukan utang piutang dalam ketentuan hukum Islam.

Praktik Martuppak Martabi yang terjadi di desa Sibargot ini memiliki relasi dilihat dari adanya integrasi dan interkoneksi pada praktik Martuppak Martabi yang tidak bertentangan dengan al-qur'an dan hadis. Praktik Martuppak. Martahi tidak bertentangan dengan hukum Islam, dan hukumnya boleh berdasarkan kaidah fikih

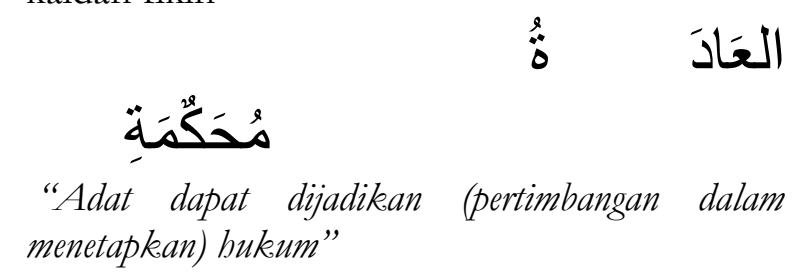

\section{DAFTAR KEPUSTAKAAN}

Almunawawarah, Tri dan Muhammad Ngasifuddin. "Praktik Utang Piutang Dalam Membangun Rumah Dengan Sistem 'Titip' Dilihat Dari Perspektif Ekonomi Syariah.” Al-Intaj: Fakultas Ekonomi Dan Bisnis Islam LAIN Bengkulu 5, no. 1 (Maret 2019).

Arriza, Muhammad Rifqi. "Teori Dan Praktek Akad Qardh (Hutang-Piutang) Dalam Syariat Islam.” Ijtibad 9, no. 2 (Sya'ban: 1436/2015).

Aziz, Abdul dan Ramdansyah. "Esensi Utang Dalam Konsep Ekonomi Islam." Bisnis 4, no. 1 (2016): 128.

Baihaki, Achmad dan Evi Malia. "Arisan Dalam Perspektif Akuntansi." Jamal: Jurnal Akuntansi Multiparadigma 9, no. 3 (Desember 2019).

Basjar, Ahmad Azhar. Asas-Asas Hukum Muamalah. Jakarta, n.d.

Cahyadi, Adi. "Mengelola Hutang Dalam Perspektif Islam." Esensi: Jurnal Bisnis Dan Manajemen 4, no. 1 (April 2014).

Creswell, John W. Penelitian Kualitatif Dan Desain Riset. Yogyakarta: Pustaka Pelajar, 2014.

Departemen Agama. Al-Qur'an Dan Terjemahannya. Bandung: CV Penerbit J-ART, 2004.

Diantoro, Giyoto. "Perlindungan Hukum Terhadap Pelaku Perjanjian Adat Dalam Transaksi Utang Piutang Dalam Perspektif Hukum (Studi Kasus Pada Unit Simpan Pinjam Masyarakat Di Desa Tenggak Kec. Sodoharjo Kab Sragen.” Jurisprudence 4, no. 2 (September 2014).

Djazuli, A. Kaidah-Kaidah Fikib. Jakarta: Kencana, 2006.

Doi, A Rahman. Muamalah Syariah III. Jakarta: Raja Grafindo, 1996.

Fanika, Noor dan Ashif Az Zafi. "Pandangan Islam Terhadap Adat Kebiasaan Hutang Piutang Masyarakat Desa Daren Kecamatan Nalumsari Kabupaten Jepara." Tafqqub: Jurnal Hukum Ekonomi Syariah Dan Akhwal Syakhsiyah 5, no. 1 (2020).

Fanika, Noor. "Pandangan Islam Terhadap Adat Kebiasaan Hutang Piutang Masyarakat Desa Daren Kecamatan Nalumsari Kabupaten Jepara." Tafaqqub: Junal Hukum Ekonomi Dan Abawl as Syabsiyah, n.d., 32.

Hasibuan, Samsuddin (Tamu Undangan), Wawancara, 23 September 2017. 
Kamil, M Srg, Nawir Yuslem, Hafsah. "Tradisi Akad Mandondon Di Masyarakat Tapanuli Selatan Ditinjau Dari Hukum Islam.” At-Tafahum: Journal of Islamic Law 2, no. 1 (JanuariJuni 2018).

Lubis, Kholillah (Masyarakat), Wawancara, 18 Oktober 2019.

Muslich, Ahmad Wardi. Fiqh Muamalah. Jakarta: Amzah, 2013.

Nurhidayah (Pelaksana Walimab), Wawancara, 20 Mei 2018.

Poerwadarminto. Kamus Besar Bahasa Indonesia. Jakarta: Balai Pustaka, 2013.

Pohan, Normaiyah (Tamu Undangan), Wawancara, 10 September 2018.

Saputri, Eviana Dwi dan Muhammad Hasyim Ashari. "Tradisi Buwuh Dalam Perspektif Akuntansi Piutang Dan Hibah Di Kecamatan Lowokwaru Kota Malang." Prive: Jurnal Ijtibat, Akuntansi Dan Keuangan 2, no. 1 (2019).

Sayyid, Sabiq. Fiqh Al-Sunnah. Beirut: Dar Al-Fikr, n.d.

Shihab, M Quraish. Tafsir Al-Misbah. Jakarta: Lentera Hati, 2002.

Sondakh, Jemmy, dkk. "Sistem Adat Pada Mapalus Rumah Etnis Tonsawang Di Tombatu Minahasa Tenggara." Lex Et Societatis 4, no. 8 (Oktober: 2018)

Syarifuddin, Amir. Garis-Garis Besar Fiqh. Jakarta: Kencana, 2010.

Syaukan, M Asy. Alnail Al Autar. Beirut: Thaba' atil As-Sani, 1997.

Tua, Mula (Pemuka Agama), Wawancara, 15 Maret 2018.

Uwaidah, Syaikh Kamil Muhammad. Fiqh Wanita. Jakarta Timur: Pustaka Al-Kautsar, 2006.

Yuswalina. "Hutang Piutang Dalam Perspektif Fiqh Muamalah Di Desa Ujung Tanjung Kecamatan Banyuasin.” Intizar 19, no. 2 (2013). 